\title{
Autoridades locais e imigrantes italianos: conflitos e consensos
}

\author{
Local Authorities and Italian Immigrants: Conflicts and Consensus
}

\section{Terciane Ângela LUCHESE ${ }^{\bullet}$}

Resumo: Este artigo analisa conflitos e consensos entre imigrantes italianos estabelecidos nas antigas colônias Conde d'Eu, Dona Isabel, Caxias e Alfredo Chaves e as autoridades locais, como diretores e demais integrantes das Comissões de Terra, no Rio Grande do Sul. A trama das relações entre os diretores e os imigrantes, demonstrou momentos de conturbação, mas também de consenso. Cada diretor, em seu tempo e em sua administração, enfrentou problemas e empenhou-se na resolução dos conflitos, de forma peculiar. A orientação da Inspetoria Especial de Terras e Colonização foi a de que os diretores agissem com prudência e negociassem com os colonos. Mas, na maioria dos ofícios dos diretores aparecem pedidos para o envio da força policial a fim de garantir a "ordem, a moral e o respeito às autoridades" nos núcleos.

Palavras-chave: Imigrantes; Autoridades; Conflitos.

Abstract: This article analyzes the conflicts and consensus between Italian immigrants established in the old colonies of Conde d'Eu, Dona Isabel, Caxias and Alfredo Chaves, and the local authorities as in the directors and other members of the Land Commissions in the State of Rio Grande do Sul. The drama of the relationship between the directors and the immigrants revealed moments of conflict but also consensus. Each director, in his term and his administration, faced problems and strived to resolve the conflicts in his own particular way. The orientation received from the Special Inspection Office for Land and Colonization was for the directors to act with prudence and negotiate with the colonists. But, in the majority of the directors' official letters, police force was requested in order to guarantee within these settlements "law and order, and respect for the authorities".

Keywords: Immigrants; Authorities; Conflicts.

[...] o político é uma das expressões mais altas da identidade coletiva. [...] O que às vezes se chama cultura política e que resume a singularidade do comportamento de um povo não é um elemento entre outros da paisagem política; é um poderoso revelador do ethos de uma nação e do gênio de um povo

(René Remond).

Tornou-se comum afirmar que os imigrantes vieram "fazer a América", numa perspectiva de heróis pacíficos e trabalhadores que sofreram muito ao serem estabelecidos nas colônias, pois lhes faltava alimentos, abrigos, as doenças ceifavam inúmeras vidas, não havia nenhuma infra-estrutura e que eles foram abandonados em meio à mata. Entretanto, com o trabalho e a perseverança, construíram grandiosas cidades. Por certo, muitas foram as privações que enfrentaram, porém, as relações entre eles e as autoridades nomeadas para organizarem os núcleos não foram pacíficas. Existiram manifestações de insatisfação que foram resolvidas pelo consenso ou pela força.

\footnotetext{
- Professora Doutora - Departamento de Educação e Ciências Humanas e do Programa de Pós-Graduação em Educação - UCS - Univ. de Caxias do Sul - Rua Francisco Getúlio Vargas, 1130, CEP: 95070-560, Caxias do Sul, Rio Grande do Sul, Brasil. E-mail: terci@terra.com.br
} 
Num contexto de interesses múltiplos, tanto do Brasil quanto da Itália, foram criados núcleos coloniais e uma estrutura jurídico-administrativa para o recebimento de imigrantes no Rio Grande do Sul. A partir de meados de 1875, Dona Isabel, Conde d'Eu e Caxias iniciavam o recebimento e o estabelecimento de colonos. Para organizar sua recepção, agasalho, medição e distribuição de lotes e a administração dos núcleos eram nomeados, pelo Governo Imperial, funcionários que constituíam a comissão de terras e a diretoria colonial.

Durante os anos de 1870 até 1876, as colônias Dona Isabel e Conde D'Eu estiveram sob administração da Província. Foram poucos os imigrantes que estabeleceram-se nesses núcleos. Administrativamente, durante esses anos, estiveram presentes as Comissões de Terra, encarregadas da medição e demarcação de lotes.

A partir de 1876 até 1884, Caxias, Dona Isabel e Conde d'Eu recebem grande número de imigrantes e foram administradas por diretores. As colônias passam a ser responsabilidade do Governo Imperial. Os diretores recebem ordens, instruções e a maioria dos funcionários foram nomeados pelo Ministério da Agricultura, Comércio e Obras Públicas. Em 1884 essas colônias são, por Decretos de n. 9183 e 9182, elevadas à condição de povoações comuns e passam a ser administradas pelos municípios de São João de Montenegro (Conde d'Eu e Dona Isabel) e por São Sebastião do Caí (Caxias), na condição de distritos. Alfredo Chaves foi criada em 1884 e permaneceu até 1889 sob a administração colonial do Governo Imperial.

As autoridades coloniais, responsáveis pela administração dos núcleos, foram elos de ligação entre os imigrantes e as esferas maiores do poder político brasileiro. Nas colônias, diretores e demais funcionários sistematizaram o processo de povoamento e relacionaram-se diretamente com os imigrantes. Enfrentaram manifestações, conflitos, discórdias, angústias e dificuldades para administrarem as colônias, o que contrapõe-se à versão historiográfica que narra a presença desses imigrantes como pacífica e laboriosa.

\section{Diretores e Imigrantes}

Março de 1879. A imigração italiana está em pleno alvorecer nas colônias Caxias, Dona Isabel e Conde d'Eu. Caxias, com 6398 habitantes ${ }^{1}$, nessa data foi palco de um conflito entre o diretor Luís Manoel de Azevedo ${ }^{2}$ e os colonos italianos Paolo Severgnani e seu filho Domenico. Na tarde do dia 22, o diretor Azevedo distribuía as cartas há pouco entregues pelo carteiro. Os colonos, em fila, diante do diretor recebiam as correspondências quando chegaram os imigrantes Paolo e Domenico Severgnani exigindo que a entrega lhes fosse feita imediatamente. O diretor, querendo impor respeito, mandou que se calassem e permanecessem na fila. Ambos "romperam em gritos e proferiram palavras insultosas" ${ }^{3}$ contra Luiz Manoel de Azevedo. Querendo contê-los, o diretor saiu 
em direção de ambos que, em disparada, correram para a rua, sendo seguidos por Azevedo. De repente, pararam e Domenico tomou uma pedra e arremessou-a contra o diretor, acertando-o no ombro. Em seu ofício, o diretor relatou que a pedra poderia ter-lhe causado a morte se lhe acertasse a cabeça. Colonos que estavam nas redondezas acudiram o diretor e o auxiliaram a prender os dois imigrantes. Ambos foram remetidos presos a cidade de Porto Alegre, por ato considerado criminoso contra a autoridade administrativa da colônia. Em ofício à Inspetoria, o diretor solicitava que eles fossem expulsos da colônia, pois "o colono Severgnani Paolo é desde muito conhecido como mau, desordeiro e autor de muitas desordens, não sendo esta a primeira vez que o referido colono tem vindo a esta Diretoria provocar-me [...]." ${ }^{4}$

No dia seguinte ${ }^{5}, 23$ de março de 1879, próximo à diretoria, estava o napolitano Luigi Cattani sentado na porta de seu açougue quando seu compatriota (também napolitano) Leonardo Morello aproximou-se e ambos passaram a discutir o ocorrido do dia anterior. Morello manifestou a insatisfação em saber que Cattani acudira o diretor, ficando contra os colonos. Aos gritos e embriagado, Morello atingiu Cattani com três facadas mortais no ventre. O sócio de Cattani, João Napolitano vendo o que ocorria partiu em direção ao agressor Morello ferindo-o com uma facada nas costas.

O diretor deu voz de prisão à Morello, João Napolitano desapareceu e Luigi Cattani faleceu no dia seguinte. O diretor Luís Manoel de Azevedo assim se manifestou a respeito do caso dizendo que "cumpria dizer que os dois indivíduos feridos achavam-se um tanto embriagados e que os agressores, Leonardo Morello e José Napolitano, eram tidos geralmente por desordeiros e assassinos mesmo." 6

A situação conflituosa está descrita no Relatório do Presidente da Província, Dr. Felisberto Pereira da Silva, de 1879. Os imigrantes Paolo e Domenico Severgnani foram, segundo o Chefe de Polícia, presos ilegalmente, sendo imediatamente colocados em liberdade no dia seguinte de sua chegada em Porto Alegre. Morello e João Napolitano seriam indiciados e julgados. Quanto ao diretor, foi imediatamente substituído por Constantino Rondelli, nomeado, em $1^{\circ}$ de abril de 1879 , diretor interino de Caxias. ${ }^{7}$

Alguns dias apenas e um saldo de três prisões, uma morte, um foragido e a mudança na direção da colônia. Como pensar em colônias pacíficas? Em imigrantes trabalhadores que não se envolveram em nenhum conflito e que não se manifestaram? Assim como em Caxias, as outras colônias vivenciaram situações parecidas.

Os diretores, apesar de representarem um poder limitado a um microespaço e não terem um prestígio maior, em nível de Província ou de Governo Imperial, representavam, de forma direta, as decisões governamentais em relação aos imigrantes. Os colonos tiveram contato direto com os diretores e as comissões de terra, pois estes efetivamente residiram no mesmo espaço e eram 
responsáveis por colocar em prática as medidas estabelecidas pelas esferas de poder estadual e federal.

As relações entre funcionários e colonos nem sempre foram pacíficas. Muitos foram os momentos em que, descontentes com as situações vivenciadas, os imigrantes manifestaram-se contra as autoridades administrativas. Outras vezes, os conflitos ocorreram entre os próprios colonos ou contra as forças policiais. Pode-se dizer que o poder era representado pelos diretores de colônia e demais funcionários, em relação à administração, mas o poder mais efetivo sobre o universo diário do colono foi o religioso. A instituição principal da Região Colonial Italiana foi a Igreja Católica que exerceu papel decisivo na formação social, cultural e política das colônias. Os padres foram autoridades muito respeitadas e atuaram como poder disciplinador na organização sócio-cultural dos imigrantes.

Os conflitos que aconteceram nas colônias tiveram diferentes conotações e envolveram situações diversas ao longo do período imperial. Entre os colonos e os diretores (ou funcionários) existiram conflitos cujo motivo principal foi a falta de pagamentos ou o atraso dos subsídios e dias de trabalhos devidos. As divergências, as manifestações e os protestos dos imigrantes foram geradas pelo não-cumprimento das promessas e pelas grandes dificuldades encontradas na sobrevivência cotidiana. As forças policiais eram requisitadas pelas autoridades a fim de legitimar a paz e impor aos colonos o cumprimento das ordens. $\mathrm{O}$ enfrentamento dos imigrantes com as forças policiais, ocasionou em diversos casos, novos problemas e violências. Entretanto, por interesses diversos, os imigrantes deveriam ser bem tratados para que a imigração espontânea pudesse crescer, conforme afirmava o Ministro da Agricultura em 1883:

Promover com o povoamento de nosso território o aumento das forças produtoras e a inoculação de sangue generoso nas veias nacionais. Organizar e manter entre as nações cultas onde superabundam braços, propaganda sincera, e facilitar ao imigrante recém - chegado, além de informações positivas, imediata colocação em prazos devolutos, medidos e demarcados, transportando-o gratuitamente o Estado até os mesmos prazos: é quanto se me afigura essencial nas circunstâncias atuais para atrair a imigração espontânea. ${ }^{8}$

Dessa forma, a orientação recebida pelos diretores era a de agirem com cautela em momentos de conflito, procurando, através do consenso e não da força, convencer os imigrantes de seus deveres. Manter a ordem e a moralidade nas colônias era essencial para atrair maior número de imigrantes. 


\section{Atuação dos Diretores: Conflitos entre Imigrantes}

Durante o período imperial, inúmeros são os registros sobre conflitos entre imigrantes. Os motivos das discórdias eram diversos: pelas diferenças políticas trazidas da Itália, pelas diferenças de nacionalidade ou por motivos mais corriqueiros como a passagem pela terra do vizinho, discórdias pela divisa de terras, brigas por embriaguez, animais que invadiam as plantações e cultivos muito próximos dos moradores. Estas situações exigiram dos diretores uma atuação no sentido de resolvê-las ou encaminhar os envolvidos para as competentes autoridades, responsáveis pelo julgamento e, conforme o caso, a punição dos culpados. Nesta parte apresenta-se um pouco dos conflitos entre os imigrantes, permeados pela ação dos diretores.

O imigrante ideal, para as autoridades, era aquele que se dedicasse ao trabalho agrícola "[...] engrandecer o Império, aumentando as forças que o promovem pela exploração das riquezas do nosso solo ubérrimo; procuramos pois antes de tudo, trabalhadores agrícolas [...]."9 Avaliando a "qualidade" dos imigrantes estabelecidos no Rio Grande do Sul, o engenheiro Manuel Maria de Carvalho afirmava que quase todos vinham acompanhados das famílias, no propósito firme de fixarem-se definitivamente na província, o que era muito conveniente. Predominavam os agricultores que se estabeleciam nas colônias, sendo resumido o número dos que procuravam as cidades. $^{10}$

Entretanto, apesar da preferência por trabalhadores agrícolas, aportaram, no Brasil, solteiros (considerados pelas autoridades como desordeiros, instigadores de conflitos), negociantes, artesãos, jornaleiros. Alguns de má índole ou mesmo com vícios como o da embriaguez. Assim sendo, os conflitos com os administradores das colônias, com a força policial e mesmo entre si, foram frequentes. Atestando a diversidade de imigrantes que foram instalados nos núcleos, em maio de 1877, o inspetor especial enviava um ofício ao agente oficial de colonização afirmando que:

Os imigrantes remetidos pelo vapor Caí vieram indicados pelo Inspetor Geral como revoltosos e desordeiros [...] que V. $\mathrm{S}{ }^{\text {a }}$ os mantenha bem vigiados $\mathrm{e}$ separados dos outros imigrantes enquanto não puder mandá-los para as colônias. Se houver algum distúrbio [...] V. S ${ }^{\text {a }}$ queira despachar um processo para dar parte do que houver ocorrido, procedendo, entretanto com toda a prudência mas, também, com toda a firmeza possível. ${ }^{11}$

O universo sócio-político-econômico e cultural em que viviam os imigrantes italianos no final do século XIX se caracterizava pela expansão do capitalismo, do processo industrial e, principalmente, pela Unificação da Itália. Sua ação política, nas primeiras décadas de chegada ao Brasil, seguiu, segundo Giron (1994, p.42), dois rumos diferentes: 
$\Rightarrow$ Buscando resolver as questões relativas às condições de vida, pela manutenção dos subsídios, distribuição de víveres, trabalho nas estradas, entre outros.

$\Rightarrow$ Enfrentando grupos de imigrantes com ideias antagônicas, como é o caso dos austríacos e italianos ou católicos e maçons.

As reivindicações pelo cumprimento de promessas e da legislação provocou conflitos entre colonos e as autoridades administrativas dos núcleos, enfoque do estudo aqui apresentado. Quanto às diferentes posturas políticas e religiosas dos imigrantes, podemos entender que:

$\Rightarrow$ Os maçons defendiam a Unificação Italiana, muitos conseguiram ascender ao poder nas colônias durante a República Velha. Era um grupo reduzido que conseguiu adaptar-se à política regional de forma satisfatória, associando-se ao governo provincial e às administrações coloniais. Segundo Giron, os maçons estavam divididos em dois grupos: os franco-maçons e os maçons carbonários. Os maçons foram os que conseguiram adaptar-se melhor à política regional $^{12}$. A primeira direção da loja "Força e Fraternidade", de Caxias, era composta por "4 brasileiros e 4 italianos, sendo que dois dos brasileiros eram fazendeiros e dois pertenciam à Comissão de Terras." (GIRON, 1994, p.42).

$\Rightarrow$ Os católicos que eram contrários à Unificação Italiana e defendiam a devolução dos territórios pontifícios ao Papa, eram os mais numerosos e contrários à maçonaria.

$\Rightarrow$ Os austríacos acreditavam ser melhor a dominação austro-húngara e eram contrários às lutas pela Unificação Italiana. Portanto, defendiam a permanência do Império AustroHúngaro sobre os territórios da Itália. Conforme Lorenzoni:

[...] os trentinos sempre mantiveram a máxima união entre eles e um grande apego e saudade de sua cara Áustria, demonstrando sempre uma certa aversão à Itália e aos italianos. E não se podia esperar coisa diferente, se pensarmos no ambiente do qual haviam chegado e a educação que tinham recebido em sua Pátria. De índole geralmente boa e pacífica, bons trabalhadores, econômicos, mas ao mesmo tempo teimosos ao extremo. [...] para que possam compreender a aversão que alguns tiroleses sempre mantiveram contra o elemento italiano, basta dizer que essa inimizade continuou, muitas vezes disfarçada e, mesmo durante a Grande Guerra, com manifestações verdadeiramente hostis (LORENZONI, 1975, p.170 - 172).

Devido às diferenças entre as concepções políticas dos imigrantes ocorreram situações que precisaram ser arbitradas pelos diretores, que as registraram.

Em um lote contínuo ao barracão da colônia Caxias, residia José Maria Vasques, imigrante espanhol, que tinha à margem da estrada uma pequena e nova plantação de milho, que não estava cercada convenientemente. Em 20 de março de 1876, o cultivo foi invadido por dois cavalos e Vasques desferiu-lhe três tiros. Um dos animais recebeu duas cargas de chumbo e o outro, uma. Vasques era descrito pelo diretor como homem de gênio e modos atrevidos e depois do ocorrido se 
apresentava continuamente armado e prometia continuar a tratar assim os invasores e não cercaria sua roça de milho. O diretor solicitava que o imigrante Vasques fosse retirado de Caxias e que os proprietários fossem reembolsados pelos prejuízos com seus animais.

Levo ao conhecimento de V. $\mathrm{S}^{\text {a }}$ um fato ocorrido nesta colônia para que se digne considerá-lo e mais apreciar a necessidade de haver neste lugar algumas praças de polícia que auxiliem a manutenção da ordem entre os colonos, em cujo número se encontram de gênios díscolos e rixosos. ${ }^{13}$

Em abril de 1876, o mesmo diretor de Caxias afirmava que a impunidade do crime que cometeu o imigrante espanhol José Vasques, pertencente ao núcleo de Caxias, teria dado motivos para que o francês João Rohá procedesse de maneira idêntica na noite do dia 12. Ele inutilizou, a tiros de espingarda, dois cavalos de propriedade de Marcos Tonelli e de Giobatta Zamboni, a pretexto de terem aqueles cavalos entrado em uma roça aberta que tinha Rohá na estrada, onde restava apenas a palha, pois o milho já fora colhido.

Os dois austríacos conspiraram contra Rohá, chegando Zamboni a cuspir na face da filha de João de apenas 12 anos. O fato fora testemunhado pelo Tenente Coronel Vasco Antônio de Medeiros e por muitos outros colonos. Imediatamente, Zamboni e Rohá, de espingardas em punho, apontavam-se um ao outro, e só a muito custo fora possível acalmá-los, sendo, então, proposta e aceita por ambos a condição de que Rohá pagasse $18 \$ 000$ réis pelo cavalo de Tonelli e $10 \$ 000$ pelo de Zamboni. Após isso, afirmava o diretor, tornaram-se amigos como antes. O diretor emitia sua opinião sobre os colonos afirmando que:

João Rohá tem por hábito embriagar-se algumas vezes; não obstante é bom chefe de família e trabalhador. Tonelli Marcos é rapaz de 19 anos, imprudente, rixoso e intolerável quando se embriaga. Giobatta Zamboni é chefe de família, mas além de possuir em grau elevado as péssimas qualidades de Tonelli, e, além de muito insolente, infame e covarde, como prova o fato que expus de insultar João Rohá na pessoa de sua inocente filha, cuspindo-lhe na face. ${ }^{14}$

O diretor considerava que os colonos Tonelli e Zamboni eram para o núcleo colonial o "pomo da discórdia", sendo urgente e indispensável suas exclusões. Afirmava que a desordem que relatara poderia ter resultado em funestas consequências. Era mais um motivo para que reiterasse o pedido de providências para que o núcleo fosse suprido com três praças de polícia montadas, número que não era excessivo para atender às diversas nacionalidades dos colonos ali estabelecidos e que entre os quais sempre se manifestava, mais ou menos, o triste efeito de suas recíprocas odiosidades. ${ }^{15}$

Em 1879, na colônia Caxias, $6^{\mathrm{a}}$ Légua, Ângelo Farroco era acusado de tentativa de homicídio contra Luiz Ferrazzs. Duas testemunhas haviam sido arroladas, Joseph Bonadnan, 38 anos, casado, 
lavrador e Baptisti Meotti, colono, casado, 35 anos. Através de intérprete, Bonadnan havia declarado que:

Há cerca de um e meio mês no corrente ano ele viu e presenciou o colono Ângelo Farroco ter com um machado, tentado matar ao colono Luiz Ferrazzs, cujo crime não consumou porque Battisti Franchisttiti aparou com um pau os golpes ou pancadas que o delinqüente desferia. Incontinente, correu para dentro de sua casa e fechou sua porta pois o fato se passou em frente a mesma casa na colônia Caxias na sexta légua. Disse-me mais que dias antes deste fato já o delinqüente tinha injuriado a mulher do ofendido com palavras. Disse mais que são testemunhas do fato de ter o delinqüente tentado com machado matar o ofendido: Baptisti Meotti. ${ }^{16}$

Outra tentativa de homicídio aconteceu na $1^{\text {a }}$ Légua de Caxias em 22 de maio de 1879. O diretor, em ofício, comunicara o Delegado Frederico Adolpho Pereira, de São Sebastião do Caí que o colono morador do lote 02 da Forqueta, Luiz Gervasoni, ao passar em frente à casa de Frederico Krause fora atacado por um cão e que para defender-se, desfechara-lhe um tiro. O dono do animal, o colono Saisceck Wenzel, enraivecido, disparara contra Gervasoni tiros, sendo que um deles o atingira na parte anterior à cabeça. Recebera cuidados da família Krause, moradores do lote 21 da Forqueta, testemunhas do ocorrido. Wenzel, após os disparos, fugira sem que soubessem onde se encontrava. ${ }^{17}$

Outras brigas entre os colonos foram registradas na Subdelegacia de Polícia de Caxias. Em 11 de setembro de 1879, João Gesoni tentara assassinar, com um machado, Josué Vacari, proprietário de um moinho em Caxias. O acusado afirmou estar embriagado. Outra briga aconteceu entre Agostino Riboldi e Giovanni Battista Riboldi. Agostino ficara com graves ferimentos, e o acusado afirmara ter agido em legítima defesa. Em 18 de outubro de 1880, era realizado um auto de corpo de delito em Raymundo de Souza de Mello, praça da polícia, ferido na parte superior do rosto, o que poderia causar-lhe cegueira ou mesmo a morte.

Em fins de 1880, o diretor de Caxias enviava ao chefe de polícia três presos daquele núcleo: José Napolitano, processado por ter ferido Leonardo Morello que se achava atualmente na cadeia da capital; Olímpio Cesar de Lima, expulso do núcleo por ser ébrio e ter mau comportamento habitual, constando, ainda, que fora expulso do corpo policial e das colônias Conde d'Eu e Dona Isabel, que ele poderia ser útil para a armada, onde prestaria bons serviços por ser dotado de muita agilidade; Afonso Amábile, expulso do núcleo pelo antecessor do diretor Bittencourt, em 18 de dezembro de 1880, por exercer profissão de médico em prejuízo da saúde dos colonos e por terem quase certeza de que ele fora o autor do incêndio da Diretoria em 5 de Dezembro de 1879. Solicitava, ainda, o diretor Bittencourt que permanecessem no núcleo colonial quatro praças das mais morigeradas, como elemento de ordem e manutenção de sua autoridade. ${ }^{18}$ 
Em 08 dias de agosto de 1881, no escritório do diretor da colônia Caxias, José Carlos Muniz Bittencourt, compareceram Domenico Bressani e Christofoli Boschetto para prestarem esclarecimentos quanto ao conflito que se dera entre ambos.

Domenico Bressani era de nacionalidade italiana, tinha 48 anos de idade, natural de Mantova, negociante estabelecido na praça Dante e relatou o seguinte:

Ontem as oito horas da noite estando em sua casa de negócio conversando com o colono Regianini Giuseppe sua mulher e filho menor, momentos depois aí entrava o colono Boschetto Christofoli que sentara-se e pedira um quarto de cachaça continuando depois de o haver servido o queixoso a conversar com o mencionado Regianini. Christofoli sem que pessoa alguma lhe dirigisse a palavra meteu-se na conversação, faltando o respeito ao Padre D. Agostino Mangon dizendo que o referido Padre seguira para Porto Alegre mas que daqui a seis meses todos os colonos conheceriam quem era D. Agostinho pois que pretendia processar todos os colonos que haviam assinado uma manifestação contra sua pessoa. O queixoso vendo que a conversação ia se encaminhando para um terreno que não lhe agradava, visto ser da vida alheia, e nesse tempo tendo-se retirado o colono Regianini, ele queixoso pediu com boas maneiras a Christofoleti que se retirasse visto ser em horas de acomodar-se com sua família, aí então principiou Christofoleti a maltratá-lo e provocá-lo... em emboscada o mesmo Christofoleti, após retirar-se o atingiu com uma paulada e depois desferiu-lhe uma facada no peito. ${ }^{19}$

O acusado, Christofoli Boschetto, tinha 43 anos, era casado, natural de Pádua, na Itália, lavrador e residente na Colônia Caxias. Declarou-se ter grande relação de vizinhança na Itália e que tinha vindo em companhia do Padre Agostino Magon daquele país e declarou que:

\begin{abstract}
Após haver bebido um pouco de cachaça, fora perguntado sobre o Padre Agostino, Bressani, então, pedira para que o mesmo se retirasse. Ele respondera que não queria. Bressani o pegara pela gola da camisa e o expulsara. De fora, após urinar percebeu que Bressani se aproximava e, com medo, tentou atingi-lo com uma madeira. O mesmo desviando-se, acabou por atingir o braço. Teria então fugido em direção de sua casa e que ao olhar para trás vira Bressani caído ao chão. ${ }^{20}$
\end{abstract}

Em setembro de 1883, Alfonso Guez, colono suíço, morador de Conde d'Eu, na Linha Santa Clara, reclamava contra o imigrante Theodoro Cousseanx que lhe havia cedido 1/3 do seu lote. Guez afirmava que o negócio fora feito pelo lote inteiro e não apenas 1/3. O diretor Antunes afirmava que as declarações e as constantes queixas apresentadas por Guez não tinham fundamento, além do que "[...] não só este colono, como outros suíços da Linha Santa Clara [...], estão bastante conhecidos nos arquivos destas Colônias pelas suas constantes reclamações, rixas e pertinências!"21

A ação dos diretores seguiu caminhos diversos. Em alguns casos, tentaram apaziguar as colônias através do consenso entre as partes envolvidas, em outros expulsaram das colônias os contraventores (e por vezes foram desobedecidos) ou então, remetiam presos os criminosos para as delegacias, procedendo, também, por vezes aos autos de corpo delito. De todas as formas, 
acreditavam que as colônias só se tornariam núcleos pacíficos se fossem mantidos grupos de força policial que pudessem garantir a execução das ordens da diretoria e arbitrar nos momentos de conflito, conforme atestam os pedidos na maioria dos ofícios apresentados à Inspetoria Especial de Terras e Colonização.

Quando, a partir de 1884, as colônias de Caxias, Conde D'Eu e Dona Isabel foram elevadas à condição de povoações comuns, passaram a ser administradas respectivamente por São Sebastião do Caí e São João de Montenegro. As câmaras desses municípios, a partir de então começaram a receber as queixas e intrigas entre os colonos.

Entretanto, conforme afirmava o engenheiro chefe das colônias Dona Isabel, Conde D'Eu e Alfredo Chaves, os problemas eram diversos.

Atendendo ao muito que V. Ex. tem feito por estas colônias e vendo diariamente o quanto se tem tornado rebeldes alguns de seus habitantes senão por índole ao menos por sugestões de outrem, venho com todo o acatamento ponderar a V. Ex. que tornam-se de dia em dia cada vez mais duvidosas as vidas daqueles que respeitando as leis do País não desprezam às dos deveres comuns.

É quase impossível contar com oito dias de tranqüilidade, pois que a cada instante surge um motivo de discórdia entre os 16 mil habitantes destes núcleos.

Até aqui os distúrbios apareciam e desapareciam entre os colonos sem maior resultado, salvo quando ocasionados por demora nos pagamentos, por que essa demora não afetava propriamente os pequenos interessados mas muito e muito aos que se julgam senhores absolutos, quero falar $=$ os vendilhões. ${ }^{22}$

O engenheiro Oliveira afirmava que naquelas colônias o que estava na "moda entre os habitantes" era o espírito de nacionalidade. Segundo ele, os habitantes eram olhados por quase todos com rancor, senão ódio e entre si os colonos queriam estabelecer a preponderância de suas nações. Como a quase totalidade da população estava constituída de dois povos rivais - os austríacos e os italianos. Os resultados disso, segundo Oliveira, seria que em tempo muito próximo as colônias se esfacelariam e talvez o Governo Imperial tivesse que passar por momentos desagradáveis, acarretando-lhe descrédito perante o mundo civilizado. Continuava, comentando que os habitantes das colônias Dona Isabel e Conde d'Eu entendiam que, pelo fato de o Governo Imperial haver transferido as mesmas para o regimento comum, por meio da emancipação, estavam eles totalmente independentes, até mesmo das leis do País, acreditando quase todos, devido à "ignorância geral", que teriam de prestar obediência somente à sociedade ali existente. O engenheiro assegurava que era preciso e urgente a manutenção de uma pequena força comandada por um oficial disciplinado a fim de fazer com que os colonos respeitassem as leis do "hospitaleiro país que eles com tanta felicidade procuraram." Alertava ainda que, em 25 de dezembro, seria necessário evitar o quanto possível qualquer agressão, pois que se efetuaria nesse dia a inauguração da Bandeira Austríaca, "festa que os italianos se opunham."23 
Além da questão dos nacionalismos, mantinham-se, nas colônias, os problemas de passagem de terras, divisas e invasões de animais. A Câmara Municipal de São João de Montenegro, em 15 de setembro de 1885, recebeu um ofício de Antônio Marangoni ${ }^{24}$ que, orientado pelo Subdelegado de Polícia de Dona Isabel, reclamava de Giuseppe Daldat ${ }^{25}$, morador do lote 27 da Linha Palmeiro, que não permitia a passagem por uma ponte ali existente a qual dividia as terras do requerente. Como Marangoni e muitas outras famílias tinham a necessidade de utilizarem aquela passagem, a Câmara deferiu despacho oficiando ao Subdelegado para que providenciasse, junto a Daldat, para que o caminho fosse aberto. Outro pedido, também referente à passagem nas terras de Pietro Poletti ${ }^{26}$, requerido por Marco Menegotto ${ }^{27}$, morador do lote 47 da Palmeiro, teve o mesmo despacho. Na Linha Pederneiras, também colônia Dona Isabel, os colonos reclamavam contra o procedimento de Luigi Zaci, que derrubara árvores na estrada que dava passagem àquelas famílias e se opunha à reabertura. A Câmara decidira que o fiscal Ramos deveria ser comunicado para que procedesse a reabertura e multasse Luigi Zaci por tal procedimento. ${ }^{28}$

Em 20 de setembro de 1887, os colonos da linha da Estrada Geral, em Dona Isabel, solicitavam providências à Câmara Municipal de São João de Montenegro, pois Luigi Zavarise ${ }^{29}$ estava construindo um moinho em frente ao lote de Vicenzo Salton (também proprietário de um moinho). Ao fazê-lo, Zavarise lançava ao rio as sobras de madeiras para represar as águas e também para prejudicar o moinho Salton. Tal procedimento estava causando um grande dano à própria estrada, já que as águas, não tendo livre curso, a invadiam. A Câmara orientou para que o fiscal tomasse as necessárias providências. ${ }^{30}$

Giovanni Gobbi ${ }^{31}$ era morador da Linha Palmeiro, no lote 34 da colônia Dona Isabel, desde 1878. Em 26 de agosto de 1888 enviou um ofício à Câmara de São João de Montenegro solicitando providências para resolver o problema de passagem. Os gêneros agrícolas por ele produzidos eram escoados pela estrada colonial que passava no lote 32 de propriedade de Francisco Foresti ${ }^{32}$, o qual o havia proibido de utilizar aquela passagem.

Antônio Segga, colono, morador da Estrada Geral n. 02 da Segunda Secção da ex-colônia Conde d'Eu, em 08 de março de 1877, afirmava que constantemente sua plantação era danifícada por animais de Achilles Braghiolli, negociante da sede. Como em Conde d'Eu não existia nenhum fiscal ou autoridade a quem pudesse recorrer, solicitava à Câmara Municipal para avaliar o dano, obrigando o proprietário dos animais a satisfazer o prejuízo. Em 03 de junho, a Câmara solicitou que o fiscal averiguasse a situação. Em novembro o fiscal dizia não ser possível decidir sobre o valor do dano, que apenas advertira Braghiolli para que o fato não se repetisse. ${ }^{33}$ Outro ofício, de colonos estabelecidos em Conde d'Eu, de 19 de maio de 1889, fazia a mesma solicitação: para que a Câmara tomasse providências em relação aos animais que constantemente prejudicavam suas lavouras. ${ }^{34}$ Por sua vez, em Dona Isabel também havia frequentes reclamações de colonos quanto à 
invasão de animais em suas terras cultivadas. É o caso do ofício enviado, em 05 de dezembro de 1888, à Câmara, pelo fiscal Horácio de Oliveira Barreto ao solicitar orientações de como deveria agir, pois dois logradouros públicos haviam sido concedidos pelo engenheiro-chefe Júlio de Oliveira a alguns colonos que passaram a cultivá-los. Entretanto, por serem logradouros públicos, os transeuntes deixavam seus animais nestes locais, o que causava a ira dos colonos que passaram a exigir indenizações e a maltratar os animais com tiros e outros ferimentos. ${ }^{35}$

A forma como os diretores agiram foi diversa: às vezes, com a força policial; outras, apaziguando as partes envolvidas e estabelecendo consensos. Conforme afirmava o diretor de Caxias, em 1876, ele se prontificava a atender todas as reclamações dos colonos morigerados, mas seria inexorável com aqueles que, pelo seu mau proceder e ociosidade, ameaçassem a harmonia que lhe cumpria manter. ${ }^{36}$ E como todos os demais diretores solicitava que:

[...] para evitar conflitos que podem alterar a ordem neste núcleo peço a $\mathrm{V}$. $\mathrm{S}^{\mathrm{a}}$ as providências precisas a fim de estacionarem neste ponto pelo menos três praças de polícia à cavalo e as nomeações de Subdelegado e suplente [...] V. S sabe que aqui existem emigrantes de diversas nacionalidades e entre estas sempre há mais ou menos odiosidades; e para evitar qualquer conflito, mormente pelos tiroleses, que são dados ao vício da embriaguez, não se pode dispensar a força pública. Já proibi expressamente a venda de bebidas alcoólicas dentro do recinto deste Núcleo, mas vale esta providência por que eles vão comprá-los daqui a 3 e 4 léguas de distância. $[. . .]^{37}$

Muitos imigrantes foram expulsos das colônias por motivos diferentes, entre eles a desobediência às ordens do diretor, por algum delito ou mesmo por "mau comportamento", como o demonstra o ofício de outubro de 1877, em que o Presidente da Província comunicava ao diretor de Dona Isabel, conforme o artigo 12 do Regulamento de 19 de janeiro de 1867, fosse expulso da colônia pelo seu mau comportamento o colono Giuseppe Capuvei. ${ }^{38}$ Em dezembro do mesmo ano, era expulso o colono Miguel Capello. ${ }^{39}$ Em Conde d'Eu, em 9 de outubro de 1877 era expulso o colono Thomaz Wolngsnveath, por mau comportamento. ${ }^{40}$ Em cumprimento à ordem do Presidente da Província de 08 de março de 1876, a partir do dia 15 fora excluído do núcleo de Caxias o imigrante francês Bretondeau, em consequência de seu mau procedimento. ${ }^{41}$

Entretanto, as ordens do diretor, muitas vezes, não eram cumpridas. No dia 26 de março de 1876, ao sair do núcleo Colonial de Caxias, o diretor encontrara, em Forqueta, o imigrante francês Bretondeau que fora expulso da colônia no dia 15. Perguntando-lhe o diretor para onde ia, Bretondeau respondeu-lhe que ia para sua casa, na colônia, e que de lá não o levariam. O diretor disse-lhe que deveria retirar-se e que lhe seria prejudicial desobedecer as ordens da Presidência. Bretondeau não o atendeu e foi para casa. O diretor afirmava que: 
Este revoltante e inqualificável procedimento da parte daquele imigrante é preciso ser coibido; por que além dele não cumprir a ordem que recebera da primeira autoridade da Província, é um mau exemplo à boa ordem que deve reinar na colônia e quem sabe tirar a força moral da diretoria. ${ }^{42}$

Para que pudesse solucionar tais desmandos, o diretor dizia precisar de uma força policial no núcleo, pois, assim, seria possível aos colonos obedecerem e seguirem as normas coloniais. ${ }^{43}$

Por motivos diversos pode-se perceber que as colônias e seus habitantes não viveram apenas trabalhando em seus lotes isolados, sem se organizar e se relacionar socialmente. Brigas, crimes, distúrbios e o desafio às ordens dos diretores eram frequentes. A participação dos comerciantes, funcionários públicos e profissionais liberais - imigrantes que permaneceram ligados às atividades urbanas - foi mais efetiva nos conflitos políticos e nas questões de nacionalidade. Já, os agricultores participaram de conflitos movidos por interesses econômicos, divisa de terras, passagem por lotes, cobrança de impostos, construção de estradas e falta de pagamentos.

\section{A Força Policial e os Imigrantes}

A presença de força policial, considerada necessária pelos diretores, a fim de garantir a paz, a ordem nos núcleos e o cumprimento das normas coloniais pelos colonos, por diversas vezes motivou novos conflitos e mesmo mortes. A violência com que agia a força policial ocasionou mais revolta e descontentamento.

Sem precisar efetivamente em que ano (1877 ou 1878), Lorenzoni registrou que próximo à taverna de Celeste Ferrari passava uma mulher proveniente da Linha Palmeiro, quando foi atacada por dois mulatos que tentaram violentá-la. Ao gritar por socorro, havia sido atendida pelo imigrante Bressan que, ao ver os dois indivíduos armados com facas, teria corrido para a casa da família Farina e, conseguindo emprestada uma pistola, socorrera a mulher. Entretanto, os indivíduos o ameaçavam com a faca e Bressan disparara. Segundo Lorenzoni, os mulatos teriam fugido para a casa de Cartier, denunciando o ataque. Cartier dera ordens ao comando do destacamento para prender Bressan imediatamente. Ao chegarem próximos ao local do ocorrido os soldados passaram a atirar e tantos foram os tiros de fuzil que um dos projéteis atingira a esposa de Celeste Ferrari e outro projétil, um colono morador da Linha Leopoldina, ocasionando a morte de ambos. Bressan não fora preso, pois já havia conseguido escapar e esconder-se em local seguro. (Lorenzoni, 1975, p.137 e 138).

Fatos lamentáveis, segundo o Inspetor Especial, haviam ocorrido em Caxias entre alguns colonos e parte da força de linha destacada naquele lugar. No sábado, 27 de outubro de 1877, o ajudante da diretoria havia feito diversos pagamentos aos colonos daquele núcleo. No domingo, 28 , houve um baile na casa do negociante Nicolau Frederich, situada no Campo dos Bugres, e lá 
estavam presentes o capitão alferes, o cadete e oficiais do destacamento. O capitão Pedro Abrelino de Oliveira constatou que um dos italianos dançava armado de um facão, e o desarmara, sem maiores distúrbios. Pouco depois, retiraram-se o capitão e alferes, ficando o cadete com alguns praças no mesmo local. Então, alguns grupos passaram a censurar o ato de desarmamento. No conflito, houve o ferimento do cadete, que imediatamente pediu auxílio ao seu superior.

O comandante do destacamento compareceu com alguma força na casa de Nicolau Frederich, dando voz de prisão ao italiano que anteriormente tinha sido desarmado, e que depois havia promovido a desordem. Ao efetuar a prisão, o italiano atirara no comandante e em seus companheiros. A tropa, em consequência, também atirara, vitimando um moço italiano que não tinha se envolvido em nada, e duas polacas, uma de nome Ana, que fora morta e a outra, de nome Rosa, gravemente ferida.

O Presidente da Província ordenou que imediatamente o delegado de São Sebastião do Caí seguisse para Caxias, acompanhado de dez praças montadas para proceder o inquérito e prender em flagrante delito os responsáveis. Temendo, porém, que a presença do comandante, cadete e praças envolvidos pudesse produzir uma excitação entre os habitantes de Caxias, o Presidente mandou retirá-los de lá e, recomendou que se empregasse, nessas comissões, só homens cuja procedência fosse garantida." 44

No ano seguinte, em 15 de fevereiro de 1878, o Presidente da Província João Chaves Campello relatou que o engenheiro encarregado da direção da colônia Caxias ${ }^{45}$ lhe havia comunicado a ocorrência de um incidente, em que duas "praças" haviam maltratado e agredido uma família ali residente, havendo o registro de mortos e feridos. O Presidente transmitiu ao Comando das Armas e para o Chefe da Polícia essa ocorrência, a fim de que fossem presos e processados os "praças" conforme regulamentava a lei. Também em Dona Isabel havia alteração da "ordem pública" por causa do atraso no pagamento aos colonos. A Inspetoria solicitou um reforço de vinte "praças de linha" para reforçar o destacamento da colônia Dona Isabel. Relatou que havia aconselhado que o diretor se encarregasse de conversar com aqueles colonos, fazendo-os entender que brevemente receberiam o que lhes era devido, acalmando os ânimos e impedindo, assim, a possibilidade de ocorrerem novos conflitos. ${ }^{46}$

Em 26 de julho de 1888, na festa de Santa Ana, realizou-se uma procissão com cerca de duas mil pessoas. O subdelegado passou pela procissão sem retirar o chapéu da cabeça e o comerciante Fortunato De Mozzi chamou-lhe a atenção, o que foi o suficiente para que o subdelegado Justino quisesse prendê-lo. Justino fazia parte da Comissão de Terras e Colonização dirigida pelo engenheiro Júlio da Silva Oliveira. Dez ou doze policiais intervieram com espadas e a procissão debandou em um instante. Imigrantes armavam-se de paus e pedras para se defenderem. No grande 
tumulto, mulheres gritavam por socorro, crianças choravam e o padre João Menegotto ficou sozinho, no meio da rua, com o ostensório nas mãos, conforme relata Lorenzoni.(1975, p.173, 174).

Em Caxias, em junho de 1888, a situação não era diferente. O alferes responsável pela regularização dos conflitos assim se referia:

Cumprindo a ordem verbal de V. S ${ }^{\text {a }}$ comunico-lhe que ao chegar em Caxias já encontrei os ânimos serenados, tendo havido porém, mais duas mortes e alguns outros conflitos fora da sede da Colônia, motivo pelo qual julgo ser indispensável uma força destacada aqui a fim de poder se conter a ordem pública e mesmo a fim de fazer algumas diligências necessárias à ordem pública. Cheguei hoje a esta Vila a fim de prestar juramento de Subdelegado e amanhã seguirei para a Colônia em companhia do Dr. Promotor Público da Comarca para colher mais alguns esclarecimentos sobre os conflitos ali havidos posto que já se achem feitos, o auto de corpo delito e inquérito policial, onde foram inquiridas oito testemunhas, que depuseram ter sido assassinado o provocador do conflito e que ignoravam quem o tinha morto. É o que me apresso em fazê-lo. ${ }^{47}$

As forças policiais enviadas para os núcleos coloniais não conseguiam estabelecer a ordem através da palavra. Todos os registros de ocorrências, nas quais os "praças" interferiram para solucionar os problemas acabaram gerando mortes e distúrbios, por vezes, maiores. Os colonos não se entendiam com as forças policiais, desconfiavam da honestidade dos administradores e, muitos, por si só, já eram desordeiros (ou já não controlavam mais seus atos ao se embriagarem).

Muitos diretores acreditavam que para conseguirem manter os núcleos coloniais em ordem era necessária a permanência de um destacamento policial para impor respeito. Entretanto, muitos colonos confrontaram-se com essas forças que, na missão de manterem a paz, foram, por vezes, motivo de conflitos. Inúmeros casos de ferimentos e mortes ocorreram devido a esses enfrentamentos. Alguns casos repercutiram na imprensa, gerando opiniões que revelam outro fator considerado importante no período da imigração: a necessidade de branqueamento da população.

[...] Pobre deste país se assim se tratar os indivíduos de nacionalidade diferente, que nele procurando o seu bem estar, a sua fortuna vivem do trabalho, contribuindo para a riqueza pública e a maior parte com famílias nacionais, por meio do casamento. [...] Só respeitando-se e garantindo-se a segurança individual, principalmente do estrangeiro, será o Brasil nação verdadeiramente adiantada e próspera. Do contrário não passará de outro império de Marrocos. ${ }^{48}$

Como a maior parte dos artigos do regulamento de 19 de janeiro de 1867 não estava sendo cumprida, segundo o diretor Bittencourtt de Caxias em dezembro de 1880, as dificuldades de administrar e cumprir os deveres a que estava encarregado eram infindáveis. Além do que, os colonos eram instigados por turbulentos nacionais e estrangeiros que estavam na colônia, apesar de terem sido expulsos, pois dificilmente se sujeitavam às ordens emanadas da diretoria. Comentava que muitos imigrantes acreditavam que certas ordens eram a expressão única da vontade do diretor; 
e havia ocasiões em que se negavam absolutamente de cumpri-las. Para que as ordens da diretoria fossem respeitadas, Bittencourtt acreditava ser necessária a permanência de uma força policial." ${ }^{49}$

A situação em que viviam as forças de linha era insustentável, segundo os relatos de alguns diretores. A pé, recebendo uma quantia insuficiente para seu sustento, era quase impossível que pudessem desempenhar com rigor a função a que se determinavam.

\footnotetext{
No Campo dos Bugres as praças deveriam ter à sua disposição montarias, muares, pois os cavalos não aturavam o escabroso caminho da Serra. Solicito para que sejam dadas ordens a respeito, a fim de que não fique o núcleo sem o apoio da força pública pois o lugar é um "refúgio dos malfeitores e desertores."

Rogo também a V. S a providenciar para que os muares sejam forrageados com milho sem o qual não há aqui animal que resista à escassez do pasto e rigoroso frio e chuvas; bem como que seja aumentado a quantia destinada ao sustento das praças, pois que se o de trezentos réis é insuficiente em S. João, aqui ainda mais pelo que tem sido preciso eu sustentar aquele dita praça, [...] muito mais difícil no Campo dos Bugres, aonde atualmente nada há a vender, e os gêneros que aparecem são de preço exorbitante. ${ }^{50}$
}

Foram diversos os enfrentamentos e conflitos entre colonos e a força policial na colônia. Ao ocorrerem esses distúrbios, imediatamente a Inspetoria Especial retirava os praças e, nos casos de morte, eram instalados inquéritos e julgados os responsáveis. O jornal "A Reforma", em 1879, destacava que a Presidência da Província solicitava a remessa dos praças do Batalhão $18^{\circ}$ Infantaria, acusados de crimes de morte e ferimentos, na Colônia Dona Isabel, para serem julgados pelo júri, em sessão convocada para o dia 15 de setembro de $1879 .^{51}$

Refletir sobre esses núcleos coloniais, nos quais imigrantes chegavam em número crescente para serem acomodados em lotes, sofriam atrasos nos pagamentos dos subsídios e distribuição de víveres, dificuldades de sobrevivência, revolta por terem sido iludidos para que emigrassem, embriaguês, diferenças culturais e linguísticas, possibilita desvendar algumas razões para a ocorrência de conflitos, crimes e todo o tipo de desordens nas colônias Conde d'Eu, Caxias e Dona Isabel.

\section{Finalizando...}

Muitos diretores permaneceram por um espaço de tempo breve devido às constantes adversidades. Outros sofreram a oposição direta dos colonos que, enfrentando dificuldades de adaptação e de sobrevivência, não hesitaram em organizar-se e exigir os pagamentos dos subsídios, dos trabalhos nas estradas e mesmo a distribuição dos víveres que lhes haviam sido prometidos.

Conflitos de interesse, discórdias entre os próprios imigrantes, problemas com alguns sacerdotes e com a cobrança de impostos foram "desordens" constantes que precisaram ser 
administradas pelos diretores. Alguns souberam, através do consenso, convencer e impor ordem e respeito na colônia, outros, utilizaram a força policial e, por vezes, acabaram por causar novos problemas.

A trama das relações entre os diretores e os imigrantes, demonstrou momentos de conturbação, mas também de consenso. Cada diretor, em seu tempo e em sua administração enfrentou problemas e empenhou-se na resolução dos conflitos, de forma peculiar. A orientação da Inspetoria Especial de Terras e Colonização foi a de que os diretores agissem com prudência e negociassem com os colonos. Mas, na maioria dos ofícios dos diretores aparecem pedidos para o envio da força policial a fim de garantir a "ordem, a moral e o respeito às autoridades" nos núcleos.

O processo de assimilação dos imigrantes não foi linear e tranquilo. O homem ao conviver com outros homens, defronta-se com dificuldades econômicas, políticas e culturais, reagindo dentro do contexto em que se insere. Os colonos reagiram frente às dificuldades e, perante seu comportamento, os diretores também posicionaram-se, muitos inclusive, abusando do poder instituído em que encontravam-se.

Para compreender o cotidiano dos imigrantes, a vivência diária, não apenas do trabalho, mas a contestação, é preciso conhecer os conflitos que ocorreram com frequência nos núcleos. Constituíse numa antítese à crença histórica do pacifismo e heroísmo do imigrante italiano. O discurso oficial influenciou a historiografia que fez dos imigrantes italianos no Rio Grande do Sul uma massa homogênea e idealizada, constituída de homens sem rosto, construída como exemplo edificante para o princípio de correlação entre "ordem e progresso" (CONSTANTINO, 1999, p.81).

Foi durante a administração de Borges de Medeiros, no intuito de reativar a imigração, que o governo assume uma postura de valorização do imigrante como elemento trabalhador, ordeiro, construtor do progresso e exemplo para os nacionais. "[...] tornava-se necessário sepultar os tempos de guerra quando os "gringos" participaram das agitações, tomaram partido ou, pior ainda, ficaram à mercê dos interesses e da sanha das duas facções revolucionárias" (CONSTANTINO, 1995, p.95).

Ao realizarmos a pesquisa foi possível constatar que, apesar do tema geral "imigração italiana" ter sido fartamente estudado, muitos são os caminhos que ainda precisam ser buscados para conhecermos, de forma mais completa, o universo colonial e o cotidiano dos colonos imigrantes que ali se estabeleceram. Este trabalho não pretende encerrar o assunto, mas contribuir para o entendimento do cotidiano nas colônias em seus primeiros anos, o processo de assimilação, adaptação e organização dos imigrantes, bem como despertar o interesse para a realização de novas pesquisas que venham a complementar a que aqui se apresentou. Conflitos entre colonos, as fricções inter-étnicas e mesmo as questões políticas trazidas pelos imigrantes (divisão entre italianos católicos, austríacos e maçons) são assuntos que necessitariam de estudos específicos, bem como a relação entre a Igreja Católica e os diretores de colônia. 
Reconstruir o rosto dos imigrantes que enfrentaram as autoridades locais, que desafiaram o poder no intuito de garantirem melhores condições de vida, indivíduos comuns que também rivalizaram entre si por suas diferenças políticas, religiosas ou étnicas. Ao mesmo tempo, compreender o posicionamento das autoridades responsáveis pelos núcleos onde eram estabelecidos os imigrantes. Encontros, relações e tramas entre pessoas de formações culturais, políticas e posições econômicas diversas que este trabalho procurou reconstituir, contribuindo para o conhecimento da história social da imigração italiana no Rio Grande do Sul.

\section{Referências Bibliográficas}

COLUSSI, Eliane Lúcia. Plantando Ramas de Acácia: a maçonaria gaúcha na segunda metade do século XIX. 1998. Tese (Doutorado em História) - PUC / RS, manuscrito, 1998. p. 284 e 285.

CONSTANTINO, Núncia Santoro de. Italianos no Processo Revolucionário. In: FLORES, Moacyr (org.). 1893 - 1895: A Revolução dos Maragatos. Porto Alegre: EDIPUCRS, 1999.

CONSTANTINO. Núncia Santoro de. Italianos, maragatos e pica-paus. In: DE BONNI, Luís A. (org.). A presença italiana no Brasil. Vol. III, Porto Alegre: EST / Fondazione Giovanni Agnelli, 1995.

GIRON. Loraine Slomp. As Sombras do Littorio: o fascismo no Rio Grande do Sul. Porto Alegre: Parlenda, 1994.

LORENZONI, Júlio. Memórias de um imigrante italiano. Porto Alegre: PUCRS / Sulina, 1975.

\section{NOTAS}

${ }^{1}$ Relatório do Ministério da Agricultura em 1879, p. 120.

${ }^{2}$ Luís Manoel de Azevedo antes de ser nomeado diretor de Caxias era o $1^{\circ}$ Escriturário da Tesouraria de Fazenda. Relatório com que o Ex. Sr. Dr. Felisberto Pereira da Silva passou a administração da Província de São Pedro do Rio Grande do Sul ao Ex. Sr. Dr. Carlos Thompson Flores em 19/07/1879. p. 32.

${ }^{3}$ Ofício n. 36 de 22/03/1879 enviado pelo diretor de Caxias, Luís Manoel de Azevedo ao Presidente da Província de São Pedro do Rio Grande do Sul, Felisberto Pereira da Silva. C250, AHRGS. Também no Relatório com que o Ex. Sr. Dr. Felisberto Pereira da Silva passou a administração da Província de São Pedro do Rio Grande do Sul ao Ex. Sr. Dr. Carlos Thompson Flores em 19/07/1879. p. 32 e 33.

${ }^{4}$ Ofício n. 36 de 22/03/1879 enviado pelo diretor de Caxias, Luís Manoel de Azevedo ao Presidente da Província de São Pedro do Rio Grande do Sul, Felisberto Pereira da Silva. C250, AHRGS.

${ }^{5}$ Ofício n. 37 de 23/03/1879 enviado pelo diretor de Caxias, Luís Manoel de Azevedo ao Presidente da Província de São Pedro do Rio Grande do Sul, Felisberto Pereira da Silva. C250, AHRGS. Também no Relatório com que o Ex. Sr. Dr. Felisberto Pereira da Silva passou a administração da Província de São Pedro do Rio Grande do Sul ao Ex. Sr. Dr. Carlos Thompson Flores em 19/07/1879. p. 33.

${ }^{6}$ Ofício no 37 de 23/03/1879 enviado pelo diretor de Caxias, Luís Manoel de Azevedo ao Presidente da Província de São Pedro do Rio Grande do Sul, Felisberto Pereira da Silva. C250, AHRGS.

${ }^{7}$ Relatório com que o Ex. Sr. Dr. Felisberto Pereira da Silva passou a administração da Província de São Pedro do Rio Grande do Sul ao Ex. Sr. Dr. Carlos Thompson Flores em 19/07/1879. p. 32 e 33.

${ }^{8}$ Relatório da Secretaria de Estado de Negócios da Agricultura, Comércio e Obras Públicas (26 ${ }^{\circ}$ relatório) - 1883 . p. 213 e 214.

${ }^{9}$ Relatório apresentado pelo Ex. Sr. Dr. Carvalho de Morais, Presidente da Província de São Pedro do Rio Grande do Sul, em 07 de março de 1874. p. 31. 
${ }^{10}$ Relatório do Engenheiro Manuel Maria deCarvalho, p. 06,

${ }^{11}$ Ofício enviado pelo Inspetor Especial de Terras e Colonização, Carlos Jansen, ao Agente Oficial de Colonização, Lourenço D'Alencastro Guimarães em 12/05/1877.

12 "A relação maçonaria e política se iniciava, via de regra, nas esferas municipais de poder. O número de dirigentes maçons identificados como políticos locais, além de bastante expressivo, é revelador de uma das principais vocações da própria maçonaria. (...) presença maciça de comerciantes e funcionários públicos (...)." COLUSSI, 1998, p.284 e 285.

${ }^{13}$ Ofício n. 41, enviado pelo diretor da colônia Caxias ao Presidente da Província de São Pedro do Rio Grande do Sul, em 21/03/1876. C 250, AHRGS.

${ }^{14}$ Ofício n. 51, enviado pelo diretor da colônia Caxias ao Presidente da Província de São Pedro do Rio Grande do Sul em 15/04/1876. C 250, AHRGS.

${ }^{15}$ Ofício n. 51, enviado pelo diretor da colônia Caxias ao Presidente da Província de São Pedro do Rio Grande do Sul em 15/04/1876. C 250, AHRGS.

${ }^{16}$ Delegacia de Polícia de São Sebastião do Caí , Inquérito Policial, 1879, Maço 41, AHRGS.

${ }^{17}$ Ofício enviado pelo diretor de Caxias, Constantino Rondelli, ao Delegado de São Sebastião do Caí, Frederico Adolpho Pereira, em 05/06/1879. Maço 41, Polícia, AHRGS.

${ }^{18}$ Ofício enviado ao Chefe de Polícia pelo diretor de Caxias, José Carlos Muniz Bittencout, em 28/12/1880. C 250, AHRGS.

${ }_{19}^{19}$ Auto de corpo de delito realizado no escritório da diretoria do núcleo de Caxias em 08/08/1881. Vítima: Domenico Bersani. Núcleo colonial de Caxias. AHRGS - Polícia - Documentação Avulsa, Maço 06.

${ }^{20}$ Auto de corpo de delito realizado no escritório da diretoria do núcleo de Caxias em 08/08/1881. Vítima: Domenico Bersani. Núcleo colonial de Caxias. AHRGS - Polícia - Documentação Avulsa, Maço 06.

${ }^{21}$ Ofício de 18/09/1883 enviado pelo diretor das colônias Dona Isabel e Conde d' Eu, Joaquim Rodrigues Antunes Júnior, para o Presidente da Província Conselheiro José Júlio de Albuquerque Barros. S A 52, AHRGS.

${ }^{22}$ Ofício enviado pelo engnheiro chefe das colônias Dona Isabel, Conde d'Eu e Alfredo Chaves, Júlio da Silva Oliveria, ao Presidente da Província, Conselheiro José Júlio de Albuquerque Barros em 15/12/1884. S A 51, AHRGS.

${ }^{23}$ Ofício enviado pelo engnheiro chefe das colônias Dona Isabel, Conde d'Eu e Alfredo Chaves, Júlio da Silva Oliveria, ao Presidente da Província, Conselheiro José Júlio de Albuquerque Barros em 15/12/1884. S A 51, AHRGS.

${ }^{24}$ Antônio Marangoni chegara em Dona Isabel em 1882 aos 44 anos, era italiano, alfabetizado, católico, casado com Maria e em 1883 tinha 3 filhos. Recenseamento da Colônia Dona Isabel em 1883, AHGM.

${ }^{25}$ Giuseppe Daldat chegara em Dona Isabel em 1880 aos 45 anos, era italiano, sabia ler e escrever, era católico, casado com Giovanna e em 1883 tinha 4 filhos. Recenseamento da Colônia Dona Isabel em 1883, AHGM.

${ }^{26}$ Pietro Poletti chegou em 1880 em Dona Isabel aos 38 anos, sendo estabelecido no lote 45 da Linha Palmeiro. Era italiano analfabeto, católico, casado com Domenica, em 1883 tinha 3 filhos. Recenseamento de 1883, AHGM.

${ }^{27}$ Marco Menegotto chegara em 1878 em Dona Isabel aos 33 anos, era italiano, católico, alfabetizado, casado com Rosa, em 1883 tinha 4 filhos. Recenseamento de 1883, AHGM.

${ }^{28}$ Ata da $3{ }^{a}$ Sessão Ordinária da Câmara Municipal de São João de Montenegro, em 15/09/1885. Códice 0058, AHGM.

${ }^{29}$ Luigi Zavarise era italiano, analfabeto, católico, casado com Elizabetta, em 1883 tinha 3 filhos. Era morador da Estrada Geral, lote 32. Recenseamento de 1883, AHGM.

${ }^{30}$ Requerimento enviado à Câmara Municipal de São João de Montenegro pelos moradores da Estrada Geral em 20/07/1887. Documentação avulsa, códice 0010, AHGM.

${ }^{31}$ Segundo o recenseamento de 1883, Giovanni Gobbi chegara em Dona Isabel em 1878, com 43 anos, era italiano, agricultor, católico, analfabeto, casado com Elena Gobbi e com 6 filhos em 1883. Censo de Dona Isabel em 1883, AHGM.

${ }^{32}$ Francisco Foresti chegara em Dona Isabel em 1876 com 35 anos, era italiano, católico, analfabeto, casado com Stefana e em 1883 tinha 6 filhos. Id. Ibidem.

${ }_{33}$ Ofício enviado por Antônio Segga para o Presidente e demais membros da Câmara Municipal de São João de Montenegro em 08/03/1887. Documentação avulsa, códice 0021, AHGM.

${ }^{34}$ Ofício enviado por colonos das imediações da sede de Conde d'Eu para o Presidente e demais vereadores da Câmara Municipal de São João de Montenegro em 19/05/1889. Documentação avulsa, códice 0061, AHGM.

${ }^{35}$ Ofício enviado pelo fiscal Horácio de Oliveira Barreto a Câmara Municipal de São João de Montenegro em 05/12/1888. Documentação avulsa, códice 0061, AHGM.

${ }^{36}$ Ofício enviado pelo fiscal Horácio de Oliveira Barreto a Câmara Municipal de São João de Montenegro em 05/12/1888. Documentação avulsa, códice 0061, AHGM.

${ }^{37}$ Ofício n. 29, enviado pelo diretor da colônia Caxias, Antônio Augusto da Costa, à Repartição Especial de Terras e Colonização, em 16/03/1876. C 250, AHRGS.

${ }^{38}$ Ofício enviado pelo Presidente da Província de São Pedro do Rio Grande do Sul ao Diretor da Colônia Dona Isabel, Ernesto Cartier em 06/10/1877. Lata 280, maço 08, AHRGS.

${ }^{39}$ Ofício enviado pelo Presidente da Província de São Pedro do Rio Grande do Sul ao Diretor da Colônia Dona Isabel, Armênio de Figueiredo em 14/12/1877. Lata 280, maço 08, AHRGS.

${ }^{40}$ Ofício de 09/10/1877 foi enviado ao diretor de Conde D'Eu, Capitão João Jacintho Ferreira pelo Presidente da Província de São Pedro do Rio Grande do Sul. 
41 Ofício enviado para a Repartição Especial de Terras Públicas pelo diretor da Colônia Caxias, Antônio Augusto da Costa em 15/03/1876. C 250, AHRGS.

${ }^{42}$ Ofício n. 46, enviado pelo diretor da colônia Caxias, Antônio Augusto da Costa, à Repartição Especial de Terras Públicas, em 16/03/1876. C 250, AHRGS.

${ }^{43}$ Ofício n. 46, enviado pelo diretor da colônia Caxias, Antônio Augusto da Costa, à Repartição Especial de Terras Públicas, em 16/03/1876. C 250, AHRGS.

44 Ofício n. 125 da Inspetoria Especial de Terras e Colonização da Província de São Pedro do Rio Grande do Sul ao Delegado de Polícia, Dr. Coelho Cintra, em 05/11/1877. Lata 280, maço 08.

45 "Cabe-me a honra de comunicar a V .Ex. que se deu um fato ontem nesta colônia lamentável. Duas praças de destacamento que aqui se achavam agrediram uma família estabelecida na sede desta colônia, mutilando o chefe da mesma família e em parte, maltratando a mulher do mesmo. O Comandante do destacamento tomou logo as devidas providências, remetendo hoje escoltadas para aí as duas praças culpadas para sofrerem o castigo segundo a lei. (...)." Ofício n. 31, enviado ao Presidente da Província Desembargador Francisco Faria Lemos em 15/02/1878, pelo diretor da Colônia Caxias. Lata 280, maço 09, AHRGS.

${ }^{46}$ Fala com que o Ex. Sr. Dr. João Chaves Campello abriu a segunda sessão da 17. legislatura no dia 12 de março de 1878. p. 09 e 10.

${ }^{47}$ Maço145 - Correspondência Expedida / Recebida pela força policial - quartel do comando geral de Porto Alegre 1888 - Signatário Francisco Riopardense de Macedo. Ofício enviado ao major Riopardense pelo Alferes Juvêncio Xavier de Abreu - sobre sua diligência em Caxias.

${ }^{48}$ Jornal diário n. 878, "A Ordem", órgão do Partido Liberal, propriedade de Ramão Alvores, de 23/09/1884, p. 3.

49 Ofício enviado em 10/12/1880, para o Inspetor Especial de Terras e Colonização, Alfredo Rodrigues Fernandes Chaves pelo diretor e engenheiro-chefe de Caxias, José Carlos Muniz Bittencourt. C 250, AHRGS

${ }^{50}$ Ofício enviado pelo diretor da Colônia Caxias ao Presidente da Província de São Pedro do Rio Grande do Sul em 24/07/1876. C 250, AHRGS.

${ }^{51}$ Jornal A Reforma, quinta-feira, 28 de agosto de 1879. Notícia da Secretaria da Polícia em 23 de agosto de 1879.

Artigo recebido em 10/2009. Aprovado em 01/2010. 